\title{
Recent advances in dietary anion-cation balance: applications in poultry
}

\section{By P. Mongin, Station de Recherches Avicoles, INRA-CRVZ, Nouzilly-37380 Monnaie, France}

The fundamental approach to this problem has already been presented elsewhere (Mongin, I980a). In brief, the main conclusions can be summarized as follows.

In order to keep its acid-base homoeostasis as close as possible to normal, the animal has to regulate the input or output of acidity or both; in other words to control the balance of acid. The net acidity intake is measured by the difference between fixed anions and cations (An-Cat) in. Likewise the net acidity output will be measured by the balance of ions excreted in the urine (An-Cat) out $_{\text {. But a third }}$ term must also be considered because some acidity is produced within the body mainly by the metabolism of dietary proteins; this is called the endogenous acid production $\left(\mathrm{H}^{+}{ }_{\text {endo }}\right)$.

When the sum of the net acidity intake plus the endogenous acid production is equal to the net acidity excreted in the urine, the animal is in steady state and the following relationship has to be verified.

$$
(\mathrm{An}-\mathrm{Cat})_{\text {in }}+\mathrm{H}^{+} \text {endo }^{-}(\mathrm{An}-\mathrm{Cat})_{\text {out }}=0
$$

Under such conditions the blood $\mathrm{pH}$ is $7 \cdot 4$, the plasma bicarbonate level is $25 \mathrm{mEq} / 1$ and the base-excess is equal to zero. However, if ( $\mathrm{I}$ ) is not verified, the so called alkali reserved or base excess (BE) of the blood will be modified accordingly to reach another steady state, thus:

$$
(\mathrm{An}-\mathrm{Cat})_{\text {in }}+\mathrm{H}^{+} \text {endo }-(\mathrm{An}-\mathrm{Cat})_{\text {out }}+\mathrm{BE}=0
$$

Equation (2) can be rearranged to give:

$$
(\text { Cat }-A n)_{\text {in }}-(\text { Cat }-A n)_{\text {out }}-\mathrm{H}^{+} \text {endo }=\mathrm{BE}
$$

to give the fundamental equation (3) to be discussed.

An example will make equation (3) more understandable. Let us assume that for some reason the net acidity excretion increases without modification of the diet. The term (Cat-An) out decreases, the first member of equation (3) increases and hence $B E$ increases. The animal becomes alkalotic. On the other hand, let us assume that part of the dietary intake of calcium carbonate is substituted by calcium chloride. The term (Cat-An) in decreases since only the fixed anions are considered and consequently BE decreases; also the animal becomes acidotic. Thus it is clear that acid-base status of the blood is a good picture of balance between anions and cations and should be used as an experimental criterion.

\section{Experimental approach}

Under usual conditions, it is difficult to measure mineral excretion and endogenous acid production but the composition of the mineral intake and the $\infty 029-6651 / 81 / 4033-5505 \$ 01.00 \bigcirc 1981$ The Nutrition Society 
acid-base status of the animal are easier to control. Thus the purpose of any experiment in this field will be to change the mineral composition of the diet and measure the acid-base balance of the animal in order to make BE equal to zero.

For food manufacturers, only the (Cat-An $)_{\text {in }}$ is of interest but it is quite complicated since it can be written exactly as follows:

$$
(\mathrm{Cat}-\mathrm{An}) \text { in }=\mathrm{mEq}(\mathrm{Na}+\mathrm{K}+\mathrm{Ca}+\mathrm{Mg})-\mathrm{mEq}\left(\mathrm{Cl}+\mathrm{SO}_{4}+\mathrm{H}_{2} \mathrm{PO}_{4}+\mathrm{HPO}_{4}\right)
$$

In practice, it is difficult to take care of the eight elements together. The two anions of phosphate are included in the diet under organic (phospho protein and phospholipid) and inorganic forms (mineral phosphate). It is not usually known whether the organic phosphates are under the mono-acid, triacid or phytate form. Furthermore, inorganic phosphate is largely incorporated as dicalcium phosphate, not to balance cations and anions in the diet but to meet the requirement in available phosphorus. So the phosphate terms in equation (4) are useless for our purpose.

On the other hand, magnesium is always included in the composition of foodstuffs and largely in excess. Likewise sulphate is just a support for trace elements or to prevent methionine breakdown. Finally $\mathrm{Ca}$ is always as a carbonate salt and primarily involved in skeletal development rather than acid-base homoeostatis.

So it appears that only $\mathrm{Na}, \mathrm{K}$ and chloride are practically useful and equation (4) becomes:

$$
(\text { Cat }-\mathrm{An})_{\text {in }}=\mathrm{mEq}(\mathrm{Na}+\mathrm{K}-\mathrm{Cl})+\mathrm{mEq}\left(\mathrm{Ca}+\mathrm{Mg}-\mathrm{SO}_{4}-\mathrm{H}_{2} \mathrm{PO}_{4}-\mathrm{H} \mathrm{PO}_{4}\right)
$$

The last term on the right-hand side can be included in the term 'endogenous production'. So the fundamental equation (3) is practically solved as:

$$
(\mathrm{Na}+\mathrm{K}-\mathrm{Cl})=(\mathrm{Cat}-\mathrm{An})_{\text {out }}+\mathrm{H}^{+} \text {endo }+\mathrm{BE}
$$

\section{Experimental results}

From the previous paragraph several practical consequences can be established with the fundamental equation (6) and I would like to give experimental proofs for most of them.

Acid-base balance $(\mathrm{Na}+\mathrm{K}-\mathrm{Cl})$. The acid-base status of the animal should indicate the ionic balance of the diet. This viewpoint is confirmed by two experimental trials.

In the first, animals fed on nine synthetic diets, having a sum $(\mathrm{Na}+\mathrm{K}-\mathrm{Cl})$ ranging from -20 to $+40 \mathrm{mEq} / \mathrm{ro0} \mathrm{g}$ diet, had a plasma bicarbonate concentration linearly related to that sum (Mongin \& Sauveur, 1973) (Fig. 1).

In the second, animals fed on eight natural diets, having the same $\mathrm{Na}$ and $\mathrm{K}$ contents but various chloride concentrations, had a marked blood $\mathrm{pH}$ dependence on dietary chloride (Hurwitz et al. 1973). The curve is sigmoidal rather than linear but this particular shape is perhaps due to diets deficient in chloride as judged by growth responses. In both instances, however, the original proposal seems to be true. 


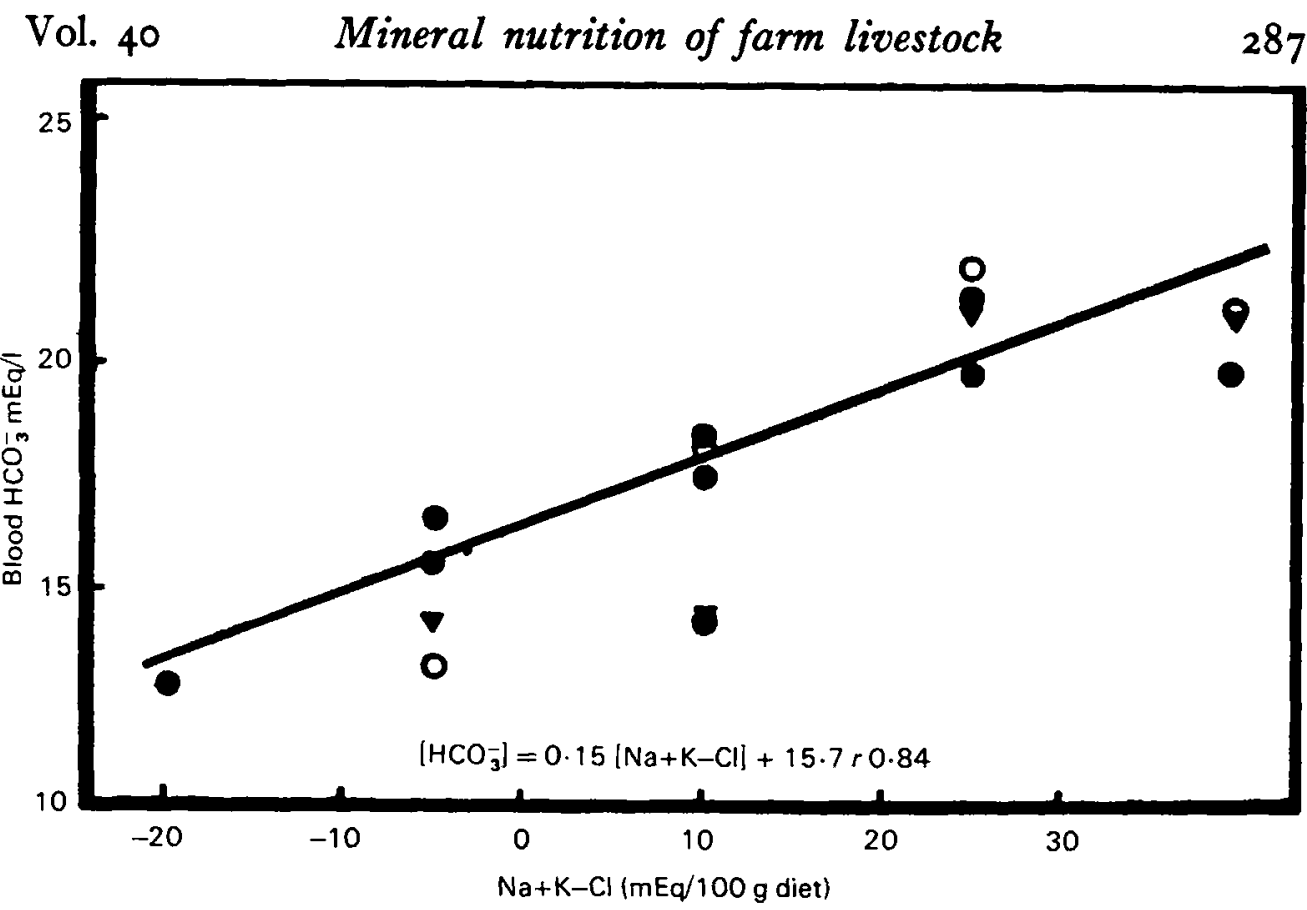

Fig. I. Relationship between mineral composition of the diet $(\mathrm{Na}+\mathrm{K}-\mathrm{Cl})$ and plasma bicarbonate concentration $\left(\mathrm{HCO}_{3}^{-}\right)$in growing chickens. (Mongin \& Sauveur, $\left.\mathrm{x}_{973}\right) . \mathrm{Na} / \mathrm{K}$ values are $(\mathrm{O}) 0.4$, (ब) $1 \cdot 0,(\nabla) 2 \cdot 5$.

Mineral balance and body growth. Systematic experiments were conducted to find out the exact relationship between cations minus anions and body growth either with synthetic diets (Nesheim et al. 1964; Melliere \& Forbes, 1966; Mongin \& Sauveur, 1973, 1977) or natural diets (Hurwitz et al. 1973; Mongin \& Sauveur, 1977). Most of the results suggest the same conclusions; this is summarized in Fig. 2. When $(\mathrm{Na}+\mathrm{K}-\mathrm{Cl})$ is higher or lower than $25 \mathrm{mEq} / 100 \mathrm{~g}$ diet, growth is depressed. When the acid-base balance is deviated towards alkalosis or acidosis, apart from the homoeostatic welfare, most of the metabolic pathways cannot work under the required optimal conditions and are more involved in homoeostatic regulation than in growth process.

Endogenous acid production and protein sources. The endogenous acid production $\left(\mathrm{H}^{+}\right.$endo $)$is primarily dependent on the nature of the protein sources for three reasons. (I) The composition of the nitrogen products varies: the proteins of purified soya give $3.9 \mathrm{mEq}$ of $\mathrm{H}^{+} / \mathrm{g} \mathrm{N}$ while those of beef give only 2.9 meq. (2) The organic phosphorus included in proteins and lipids increases $\mathrm{H}^{+}$production: egg yolk phospholipids and soya phosphatides give $13.8 \mathrm{mEq}$ of $\mathrm{H}^{+} / \mathrm{g}$ of $\mathrm{N}$. (3) The mineral composition of the natural protein sources is highly variable.

From a practical stand point the food compounder cannot control the endogenous acid produced during the metabolism of the protein, but he may estimate the mineral composition of protein foodstuffs and hence adjust the $(\mathrm{Na}+\mathrm{K}-\mathrm{Cl})$ of the diet to make the relative $\mathrm{BE}$ equal to zero. 


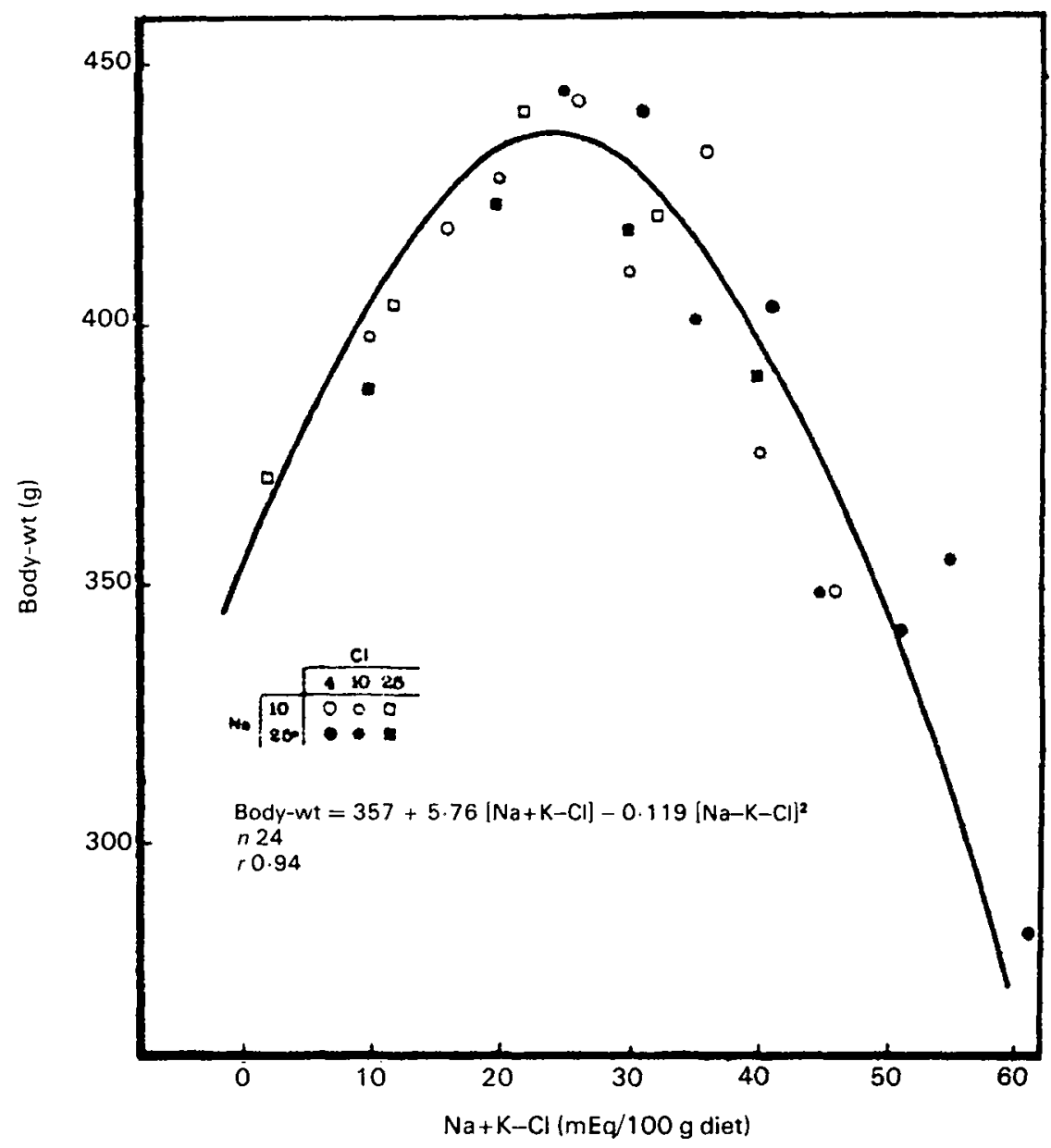

Fig. 2. Body-weight at 4 weeks of age in relation to the value of $(\mathrm{Na}+\mathrm{K}-\mathrm{Cl})$ expressed in $\mathrm{mEq} /$ $100 \mathrm{~g}$ diet (Mongin \& Sauveur, 1977).

The main protein source in poultry nutrition is soya bean, but for several reasons other sources can be used (rapeseed or meat meal). A substitution of soyabean protein by another protein source leads to a modification of the anion-cation balance and usually the feed manfacturers are not aware of this. In Table I, different situations are presented to illustrate the variation of $(\mathrm{Na}+\mathrm{K}-\mathrm{Cl})$ in a diet for laying birds when part of the soya bean content is replaced by other protein sources. When half the soya bean content ( $50 \%$ protein) is substituted by fish meal ( $75 \%$ protein), the $(\mathrm{Na}+\mathrm{K}-\mathrm{Cl})$ value is reduced by 3 points. The same reduced value is given by a weight to weight substitution of half the soya bean (50\% protein) by meat meal (50\% protein).

Similar comparisons are presented for sunflower and peanut meal.

The next point to be considered is the large variability in the mineral composition of the protein sources other than soya bean (Mongin \& Sauveur, 1976). To some extent the, so called, quality of such $\mathrm{N}$ sources can be improved by 
Table 1. Variation of $(\mathrm{Na}+\mathrm{K}-\mathrm{Cl})$ in a diet in which soya-bean protein is replaced by other protein sources*

(Mongin, 1980)

$\%$ of soya-bean protein:

$\%$ of other protein source...

\begin{tabular}{ccccc}
\multicolumn{4}{c}{$\mathrm{Na}+\mathrm{K}-\mathrm{Cl}$} \\
$20: 0$ & $17: 2$ & $14: 4$ & $11: 6$ & $8: 8$ \\
17.42 & 16.35 & 15.27 & 14.20 & 13.13 \\
17.42 & 16.42 & $15.4 \mathrm{I}$ & $14.4 \mathrm{I}$ & 13.41 \\
17.42 & 16.84 & 16.26 & 15.68 & 15.10
\end{tabular}

Soya bean $(50 \%$ protein $)+$ fish meal $(75 \%$ protein $)$

Soya bean $(50 \%$ protein) + meat meal ( $50 \%$ protein)

Soya bean $(50 \%$ protein $)+$ sunflower or peanut meals ( $42 \cdot 5 \%$ protein)

$\begin{array}{lllll}17.42 & 16.84 & 16.26 & 15.68 & 15 \cdot 10\end{array}$

-Assuming that ( 1 ) the protein content remains constant (soya + other protein $=10 \%$ crude protein), (2) corn plus protein sources represent $88.5 \%$ of the diet, (3) other mineral sources are not included.

adjustment of their mineral balance. The literature is full of examples but I will take two of them from the work of Miller (1969).

In a first experiment Miller (1969) improved menhaden fish meal by various mineral mixtures which included chloride, carbonate and sulphate. When the sum $\left(\mathrm{Na}+\mathrm{K}-\mathrm{Cl}-\mathrm{SO}_{4}\right)$ is calculated for each diet from his results and plotted against body-weight, all the points fall on the same line (Fig. 3).

In another experiment (Miller \& Kifer, 1969), the sole addition of $1 \%$ bicarbonate into a menhaden fish meal improved growth by $23 \%$ (Fig. 4) and the effect of glutamic acid is either negative when included as the $\mathrm{HCl}$ salt or positive when included as the free form. As shown in Fig. 4 the imbalance between anions and cations explains $93 \%$ of the variability in growth responses while glutamic

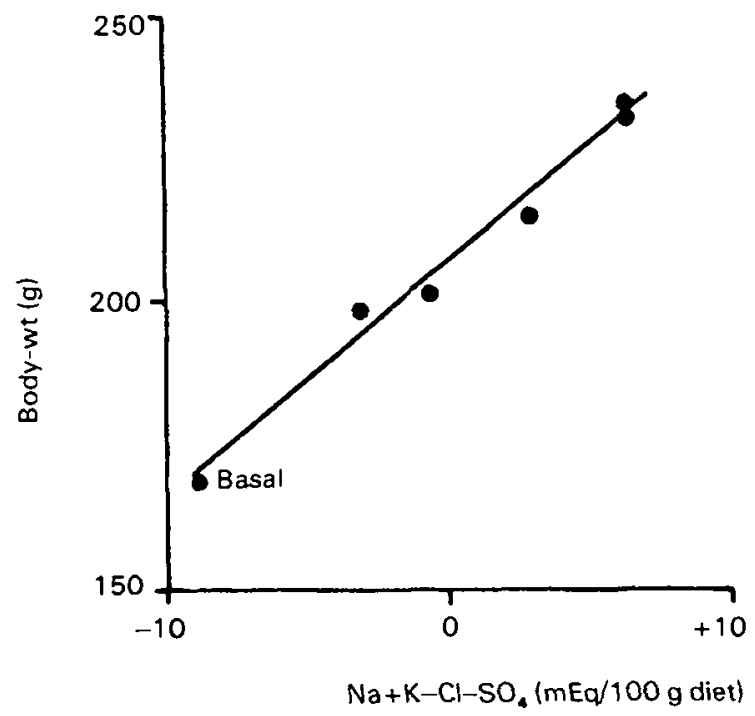

Fig. 3. Body-weight gain related to anion and cation balance. Several diets based on fish meal are assayed with different mineral mixtures to improve the so-called quality of that protein (Miller, 1969). 


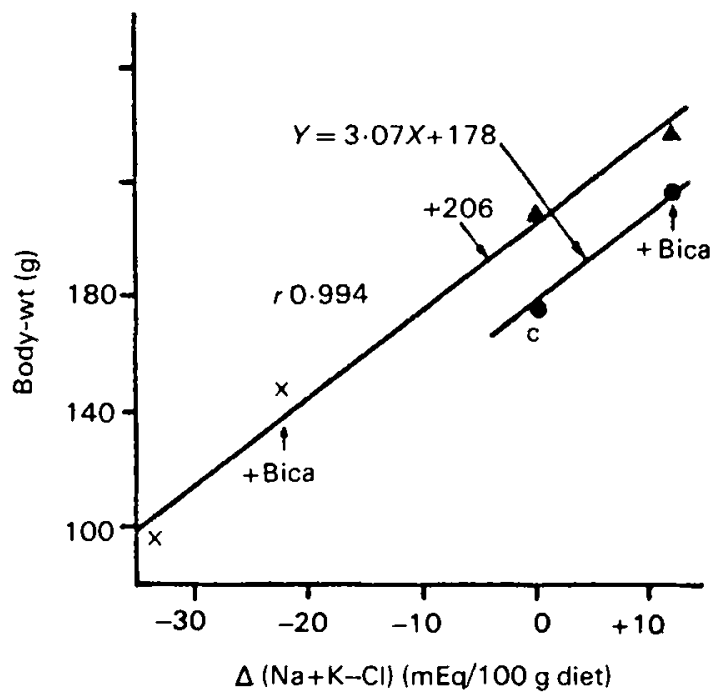

Fig. 4. Effect of glutamic acid as free form $(\Delta)$ or as $\mathrm{HCl}(x)$ and bicarbonate (Bica) on growth response of a menhaden fish meal as sole source of protein (Miller \& Kifer, 1969).

acid takes into account only $5.8 \%$ of that variability. From this standpoint the amino acid requirements obtained from experiments made with synthetic diets or by addition of pure amino acids in the $\mathrm{HCl}$ form have to be reconsidered. In most cases the beneficial effect of a single amino acid was overcome by the excess of chloride.

A good illustration is given by O'Dell \& Savage (1966). Using a casein basal diet (Fig. 5), body growth can be modified by variations of the anion-cation balance as well as by the amino acid composition of the diet. But to reach a given rate of body growth, it is obvious that the arginine and lysine requirements depend on the mineral balance. The addition of $2.7 \%$ potassium acetate to a diet with $0.6 \%$ arginine added to it, gives the same improvement in body growth as a diet with $2 \%$ arginine plus $2 \%$ lysine added.

Divalent cation intake and mineral balance. In the fundamental approach, the faecal excretion has been always neglected in the balance. Usually it is quite constant and the causes of mineral partition between urine and faeces are largely ignored, especially those related to divalent cations. But a simple rule can be given as long as we are dealing with monovalent ions. The fundamental relation remains true but it is not truly exact with divalent ions as shown in the following example. Let us assume that, on a milliequivalent basis, part of the $\mathrm{NaCl}$ or $\mathrm{KCl}$ content of a diet is replaced by $\mathrm{CaCl}_{2}$. All of these are neutral salts and they should not induce alkalosis or acidosis. However, $\mathrm{CaCl}_{2}$ makes birds acidotic. In fact, the $\mathrm{Ca}$ is not absorbed to the same extent as the $\mathrm{Na}$, while the chloride ion absorption remains the same. In the distal part of the digestive tract, chloride is exchanged for bicarbonate and $\mathrm{Ca}$ is excreted in the faeces as $\mathrm{CaCO}_{3}$. Over-all, blood bicarbonate ions are exchanged for chloride ions and make the bird acidotic. A good illustration is given by Melliere \& Forbes (1966) as shown in Fig. $6 . \mathrm{HCl}$ was mixed into a diet 


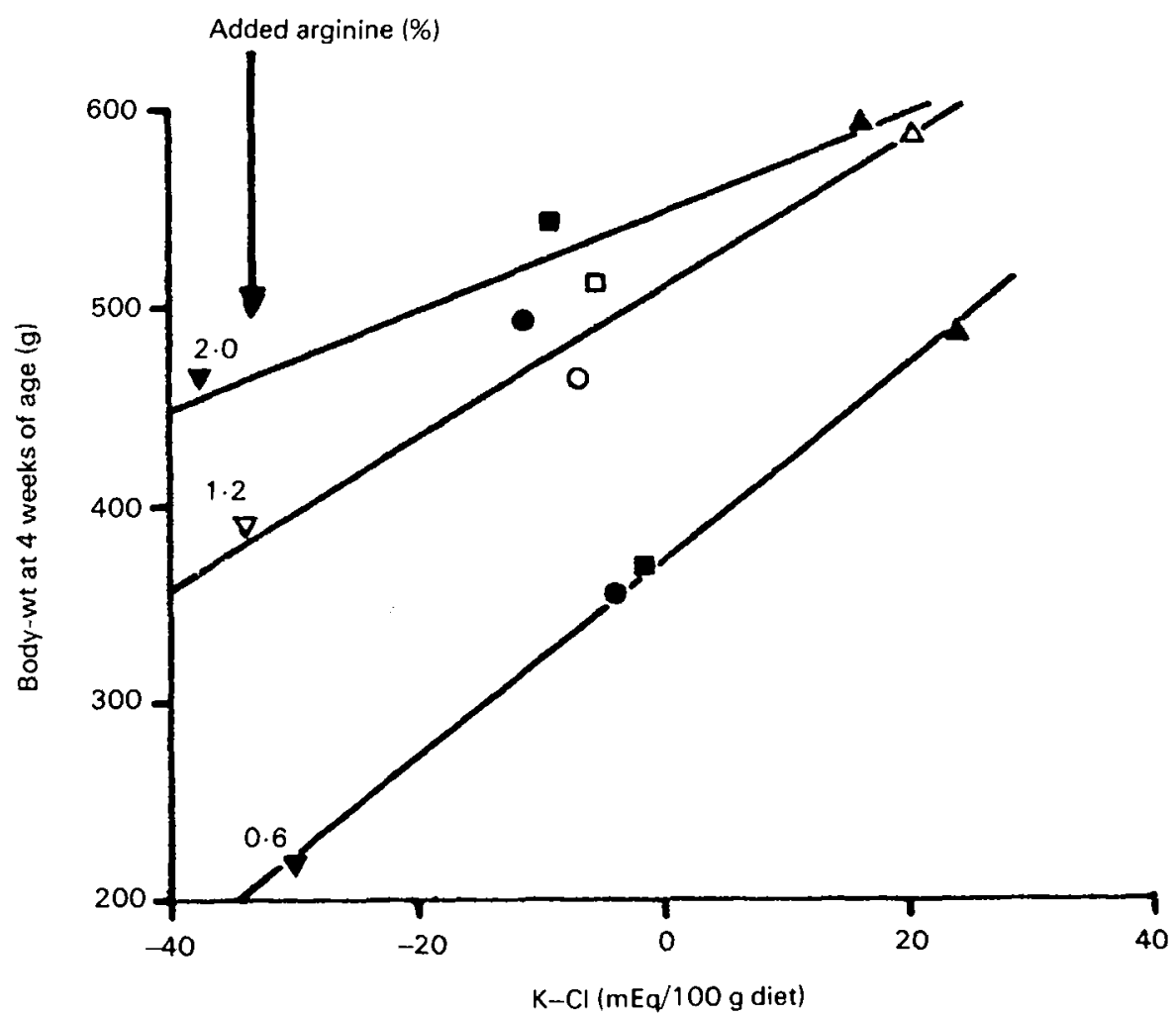

Fig. 5. Effect of arginine, lysine and potassium acetate added to a casein basal diet on body growth. ( $(\mathbf{)}$ casein basal diet, $(\nabla)$ basal $+20 \mathrm{~g}$ lysine hydrochloride $/ \mathrm{kg},(\Delta)$ basal $+27 \mathrm{~g}$ potassium acetate/kg, ( $\mathbf{(})$ basal + both supplements (from O'Dell \& Savage, Ig66).

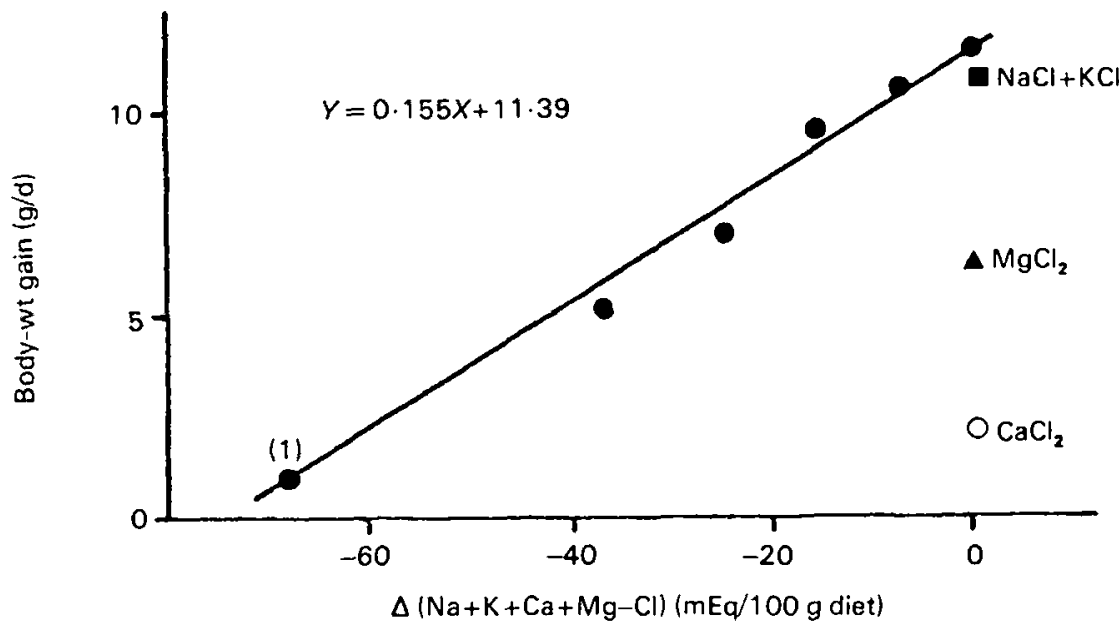

Fig. 6. Effect of mono and divalent cations on body-weight gain (Melliere \& Forbes, 1966). 
to give up to $2 \cdot 4 \mathrm{I} \%$ added $\mathrm{Cl}$. Body-weight gain correlated well with the dietary cations minus anions. When the same amount of chloride $(2.41 \%)$ is added as a mixture of $\mathrm{NaCl}$ and $\mathrm{KCl}$, the rate of body growth is comparable to that obtained with no added chloride. Conversely, $2 \cdot 4 \mathrm{I} \% \mathrm{Cl}$ added as $\mathrm{CaCl}_{2}$ is almost as bad as when added as $\mathrm{HCl}$ while $\mathrm{MgCl}_{2}$ is in between these values. It can be calculated that only $12 \%$ of $\mathrm{Ca}$ and $52 \%$ of $\mathrm{Mg}$ is absorbed while $95 \%(\mathrm{Na}+\mathrm{K})$ is absorbed.

Such results justify a posteriori the fact that in equation (6) I did not include $\mathrm{Ca}$ and $\mathrm{Mg}$ into the dietary cations. However, the reader has to bear in mind the reasons and adjust the equation when needed.

Intake of ions and humidity of droppings. In birds, water intake depends on salt intake (Mongin, $1980 b$ ). In practice a relationship between excess $\mathrm{Na}$ intake and excess humidity of the litter is well known. But less attention has been paid to the other dietary ions. In fact, the chloride anion is not related at all to the humidity of droppings (Vogt, 1971), but $\mathrm{K}$ and $\mathrm{Na}$ are the main causes of wet droppings. Thus any increase of the dietary $(\mathrm{Na}+\mathrm{K})$ will increase water consumption and water content in the excreta.

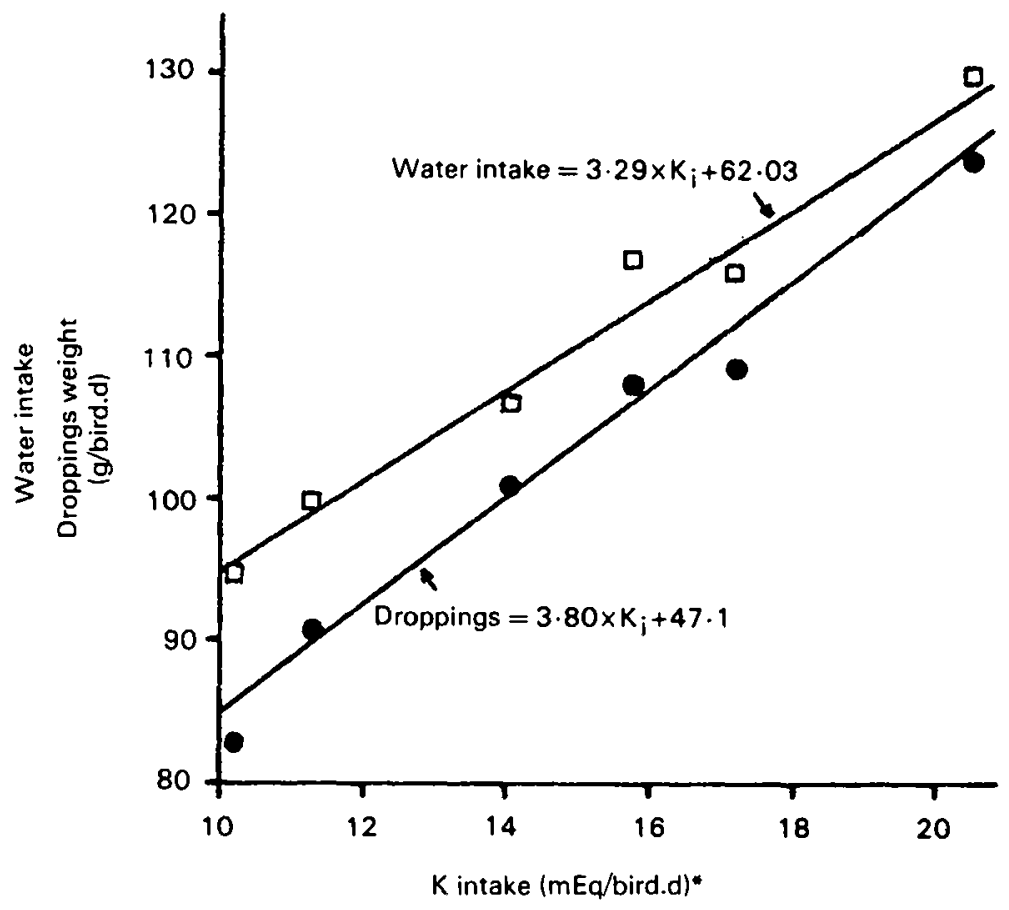

Fig. 7. Water intake ( $\square$ ) and weight of wet droppings $(O)$ as a function of potassium intake. (James \& Wheeler, 1949).

Immature birds are fed with 150,200 or $25^{\circ} \mathrm{g}$ crude protein $/ \mathrm{kg}$ diets. The 200 and $250 \mathrm{~g}$ crude protein $/ \mathrm{kg}$ diets are made from the $150 \mathrm{~g} / \mathrm{kg}$ diets by substitution of corn for soya bean. The increased $\mathrm{K}$ content of the diets explains water intake and the amount of wet droppings as well as protein content. Assuming that $150 \mathrm{~g}$ protein $/ \mathrm{kg}$ diet is achieved with $800 \mathrm{~g}$ com $+160 \mathrm{~g}$ soya bean $/ \mathrm{kg}$ which gives $7 \mathrm{~g} \mathrm{~K} / \mathrm{kg}$ diet. 
This viewpoint is perfectly illustrated by the results of James \& Wheeler (1949). They increased the dietary protein content by a substitution of corn by soya meal, to get diets containing 15,20 and $25 \%$ protein. They observed an increase in water intake and the amount of droppings produced by growing chickens and postulated a relationship between $\mathrm{N}$ and water metabolism. But if we take into consideration the fact the $\mathrm{K}$ concentration in soya bean is 6.5 -fold higher than in corn, $\mathrm{K}$ intake almost doubles and may also explain the results presented in Fig. 7. Thus among the possible causes of wet droppings, dietary $\mathrm{K}$ load is largely ignored, though it may be one of them.

\section{Limits of the method}

As shown in this paper, the control of the sum of $(\mathrm{Na}+\mathrm{K}-\mathrm{Cl})$ in a poultry diet can be useful. But this method has its own limits.

The first one is a situation where one of the dietary minerals in question is deficient, i.e., below the minimum requirement. The deficiency is the first limiting factor and any adjustment of $(\mathrm{Na}+\mathrm{K}-\mathrm{Cl})$ will not improve anything.

The other one is due to the excess of one mineral. It becomes toxic and the alteration of $(\mathrm{Na}+\mathrm{K}-\mathrm{Cl})$ is useless under such conditions.

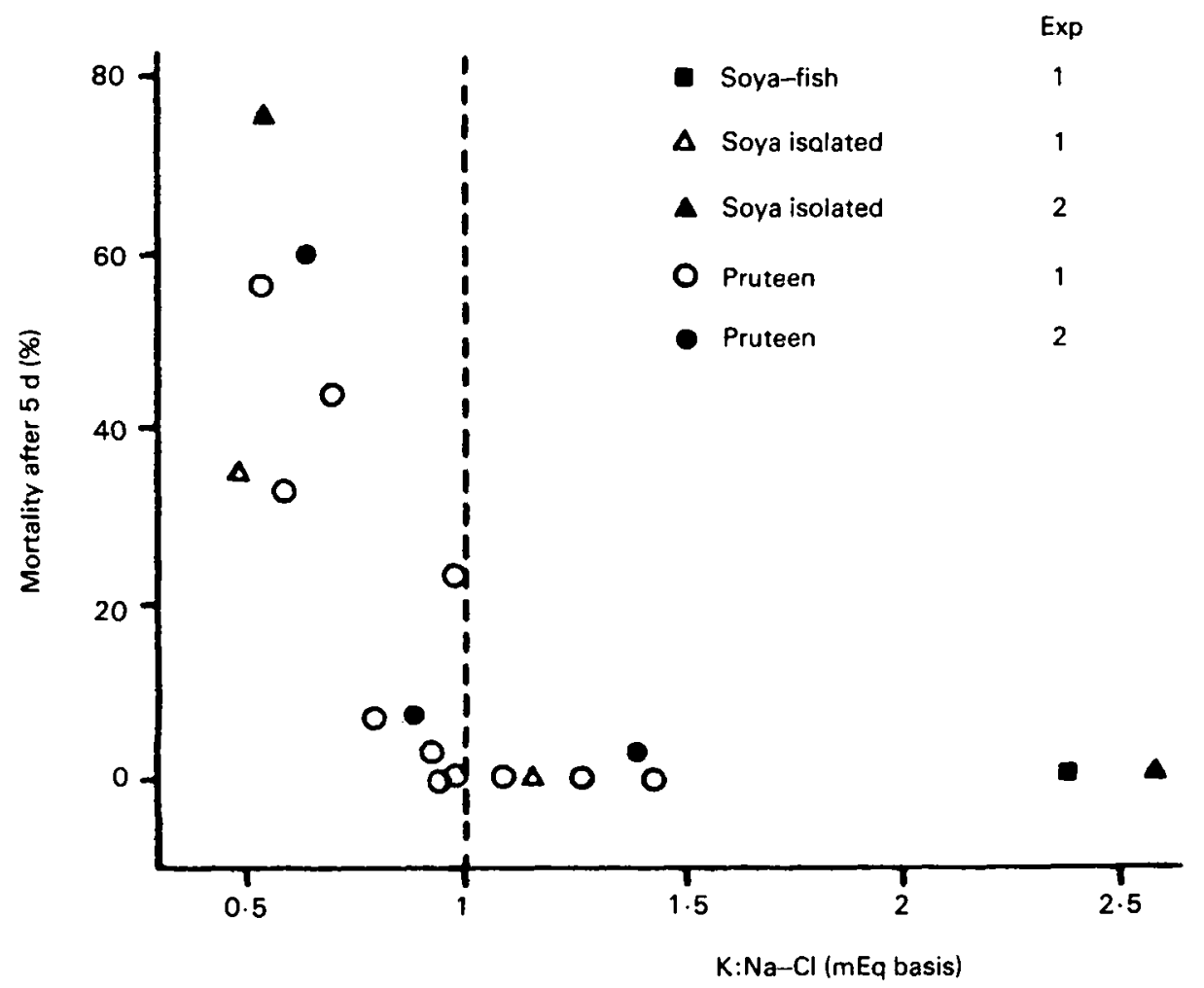

Fig. 8. Mortality of chicks fed on high-sodium diets supplemented with different amounts of potassium and chloride (Talbot, 1978). 
The last point to be discussed is the Na content of the diet relative to that of $\mathrm{K}$. We found (Sauveur \& Mongin, 1974) that chicks tolerate $\mathrm{K}$ better than $\mathrm{Na}$ at a given value for $(\mathrm{Na}+\mathrm{K})$. Recently Talbot $(1978)$ found that the toxic effect of excess $\mathrm{Na}$ as measured by mortality can be overcome by addition of $\mathrm{K}$ or chloride. $\mathrm{He}$ concluded that the value of the ratio $\mathrm{K}+\mathrm{Cl}: \mathrm{Na}$ must be higher than unity in order to avoid mortality in chicks. Since our advice is to keep $(\mathrm{Na}+\mathrm{K}-\mathrm{Cl})$ as close as possible to $25 \mathrm{mEq} / \mathrm{ro0} \mathrm{g}$ diet, the following equations must be solved together:

$$
\text { (a) } \mathrm{Na}+\mathrm{K}-\mathrm{Cl}=25 \quad \text { and (b) } \frac{\mathrm{K}+\mathrm{Cl}}{\mathrm{Na}}>_{1} \text {. }
$$

It comes out that $\mathrm{K}$ must be higher than $12.5 \mathrm{mEq}$ (or $0.5 \%$ ) and consequently $(\mathrm{Na}-\mathrm{Cl})$ must be lower than $12.5 \mathrm{mEq} / 100 \mathrm{~g}$. Looking in detail the results of Talbot (1978) this conclusion is about right indicating that $\mathrm{K}$ may counteract the toxic effect of $\mathrm{Na}$ as shown in Fig. 8.

\section{REFERENCES}

Hurwitz, S., Cohen, I., Bar, A. \& Bornstein, S. (1973). Poult. Sci. 52, 903.

James, E. C. \& Wheeler, R. S. Jr (1949). Poult. Sci. 28, 465.

Melliere, A. L. \& Forbes, R. M. (1966). F. Nutr. 90, 3ro.

Miller, D. (1969). Poult. Sci. 48, 1535.

Miller, D. \& Kifer, R. R. (1969). Poult. Sci. 48, 1327.

Mongin, P. (1980a). Proc. 3rd Ann. Int. Miner. Conf. Orlando, Florida, Jan. 16, 1980.

Mongin, P. (1980b). Proc. Florida Nutr. Conf. p. 213 . Orlando, Florida.

Mongin, P. \& Sauveur, B. (1973). In Journées Avicoles et Cunicoles, Paris.

Mongin, P. \& Sauveur, B. (1976). Ind. Alim. Anim. 9, 49.

Mongin, P. \& Sauveur, B. (1977). In Growth and poultry meat production, 4, 235 [K. N. Boorman and B. J. Wilson, editors]. Edinburgh: British Poultry Science Ltd.

Nesheim, M. C., Leach, R. M., Zeigler, T. R. Jr \& Serafin, A. (I964). F. Nutr. 84, 36r.

O'Dell, B. L. \& Savage, J. E. (1966). F. Nutr. 90, 364 .

Sauveur, B. \& Mongin, P. (1974). XVth Wld Poult. Congr. New Orleans, p. 180.

Talbot, C. J. (1978). Proc. Nutr. Soc. 37, 53A.

Vogt, H. (1971). Arch Geflugelk. 4, I5I. 